\title{
The Acari Hypothesis, II: Interspecies Operability of Pattern Recognition Receptors
}

\author{
Andrew C. Retzinger $1, *\left(\mathbb{D}\right.$ and Gregory S. Retzinger ${ }^{2} \mathbb{D}$ \\ 1 Department of Emergency Medicine, Camden Clark Medical Center, West Virginia University, \\ Parkersburg, WV 26101, USA \\ 2 Department of Pathology, Feinberg School of Medicine, Northwestern University, Chicago, IL 60611, USA; \\ gretzing@nm.org \\ * Correspondence: andrew.retzinger@gmail.com
}

check for updates

Citation: Retzinger, A.C.; Retzinger, G.S. The Acari Hypothesis, II: Interspecies Operability of Pattern Recognition Receptors. Pathogens 2021, 10, 1220. https://doi.org/ 10.3390 / pathogens 10091220

Academic Editor: Diana

Gerardi Scorpio

Received: 2 September 2021

Accepted: 14 September 2021

Published: 21 September 2021

Publisher's Note: MDPI stays neutral with regard to jurisdictional claims in published maps and institutional affiliations.

Copyright: (c) 2021 by the authors. Licensee MDPI, Basel, Switzerland. This article is an open access article distributed under the terms and conditions of the Creative Commons Attribution (CC BY) license (https:// creativecommons.org/licenses/by/ $4.0 /)$.

\begin{abstract}
Hypersensitivity to galactose- $\alpha$-1,3-galactose ( $\alpha$-gal) is an informative example of a pathologic IgE-mediated process. By way of their saliva, ticks are able to sensitize humans to tick dietary elements that express $\alpha$-gal. Mites, which along with ticks constitute the phyletic subclass Acari, feed on proteinaceous foodstuffs that represent most, if not all, human allergens. Given: (1) the gross nature of the pathophysiological reactions of allergy, especially anaphylaxis, (2) the allergenicity of acarian foodstuffs, and (3) the relatedness of ticks and mites, it has been hypothesized that humanacarian interactions are cardinal to the pathogenesis of allergy. In this report, a means by which such interactions contribute to that pathogenesis is proposed.
\end{abstract}

Keywords: acari hypothesis; ticks; mites; IgE; vector; ixoderin; fibrinogen-related protein (FReP); interspecies operability

\section{Background/Introduction}

Although there exists a link between human allergens and acarians [1-9], mere contact between humans and acarians cannot account for allergic inflammation. After all, mites are ubiquitous within the modern human habitat, existing as synanthropic organisms within human dwellings [10], as parasites of human foodstuffs [11-16], and as permanent ectoparasites on human skin [17]. In addition, although such ubiquity ensures nearcontinuous human-acarian interaction, the low prevalence of acarian-targeted adaptive responses seems incongruous. Nevertheless, the localization and scale of IgE-mediated mechanical reflexes on epithelial surfaces argue persuasively that the ectoparasite is, in fact, the target of the adaptive response [18]. Inasmuch as the principle acarian threat to mammalian immunity is vectorial, it seems likely this threat drives the mammalian adaptive response. More precisely, the mammalian immune system recognizes and uses pathogen-bound acarian operators, thereby linking the pathogen to the vector and directing an adaptive anti-vector response.

Mammalian innate immunity is orchestrated by pathogen recognition receptors (PRRs) that identify pathogen-associated molecular patterns (PAMPs) expressed on the membranous surfaces of microorganisms. Binding of PRRs to PAMPs prompts a variety of immune phenomena, including complement activation and phagocytosis [19-21]. Sans an adaptive arm, acarian immunity functions in similar fashion. The humoral defense of acarians, like that of mammals, is based on the activity of PRRs and effector molecules, including lectins, complement-like molecules and antimicrobial peptides [22]. Relatedly, the cellular immunity of acarians involves leukocyte equivalents, i.e., hemocytes, that phagocytize, encapsulate, and digest foreign elements in opsonin-dependent fashion [22,23].

The coexistence of pathogens and housekeeping opsonins in acarian salivary glands and gut $[22,24]$ makes it a certainty that complexes comprised of both are transmitted in acarian saliva and/or stool when an acarian interacts with a human, Figure 1. 


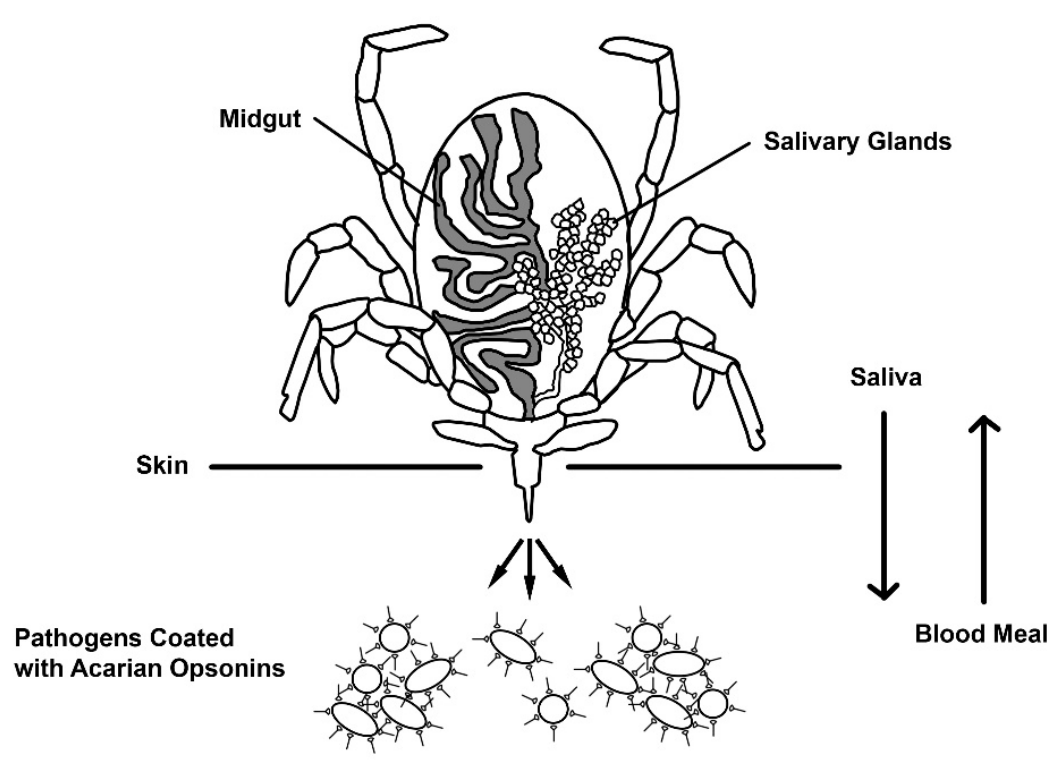

Figure 1. An acarian transmits its opsonized pathogens. The image shows only one means by which such pathogens might be transmitted, here, via hematophagous route. Other means of transmission might include inhaling or consuming the opsonized pathogen or, alternatively, the living vector, allowing for continuous deposition of opsonized pathogens on an epithelial surface. Adapted from [25].

Because molecular elements derived from dietary materials also populate acarian salivary glands and gut, they, too, undoubtedly admix with the other reactants, forming higher order complexes. Such complexes may be attributed 'inappropriately' to the acarian itself, Figure 2, prompting, ultimately, an adaptive response to the dietary materials rather than to the acarian. As elaborated next, homologies between certain acarian and human immune effectors provide clues as to how an adaptive, anti-vector response-whether felicitous or specious-might be achieved.

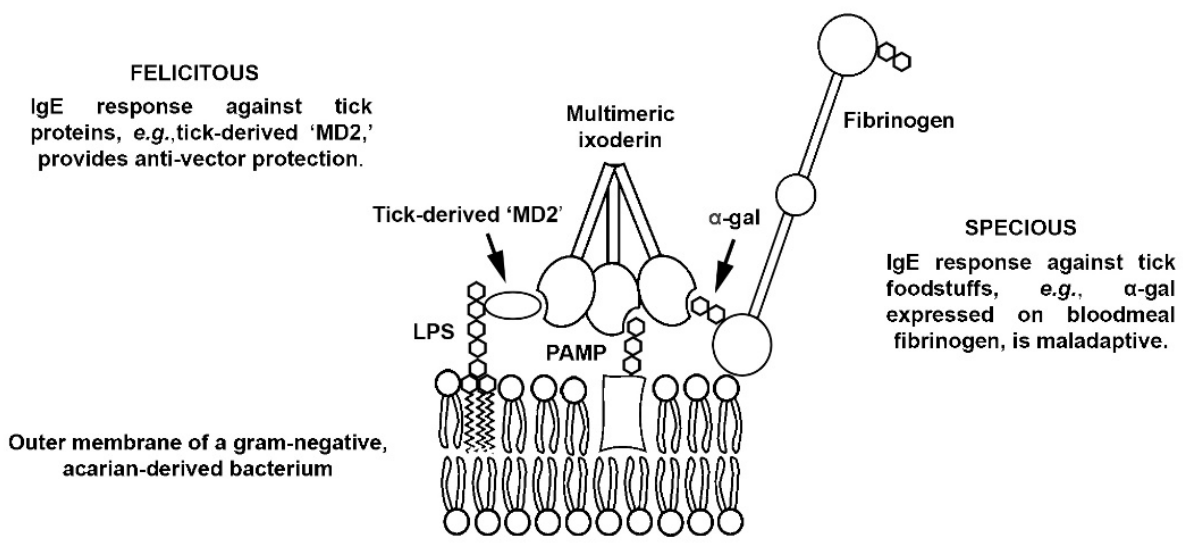

Figure 2. Pictorial representation of a proposed quaternary complex formed between an acarian pathogen (e.g., a gram-negative bacterium), an acarian 'tag' protein (e.g., tick 'MD2'), an acarian opsonin (e.g., multimerized ixoderin) and an acarian foodstuff (e.g., fibrinogen expressing $\alpha$-gal). The adaptive immune responses elicited by the complex include: (1) felicitous anti-vector, i.e., anti-acarian, IgE directed against the tag protein, (2) specious IgE directed against the foodstuff, (3) felicitous Ig directed against the pathogen. See text for details.

Although the immune system of mites is not yet well-characterizedthat of ticks is, especially that of ticks of the genus Ixodes, including I. ricinus, a causative agent of $\alpha$-gal hypersensitivity in Europe [26]. Contained within both saliva and hemolymph of these 
ticks are ixoderins [27], well-described members of a family of acarian PRRs that function as opsonins [24]. Analysis of the genome of Ixodes ticks reveals 27 genes encoding three groups of ixoderins, i.e., A, B and C [24]. The ixoderins are well-conserved, with homologs identified in other tick genera, including Amblyomma [28], the tick responsible for $\alpha$-gal sensitization in the United States. In Ornithodoros moubata, the opsonin, Dorin $\mathrm{M}$, is a homolog of Ixoderin A $[24,29,30]$.

The ixoderins have significant homology with ficolins, Figure 3 and Table 1, a family of human PRRs. Both are members of a larger group known collectively as fibrinogen-related proteins (FRePs) [31], the shared feature of which is a C-terminal domain homologous with the C-terminus of the $\gamma$-chain of the eponymous fibrinogen. Indeed, the fibrinogenrelated domain $(\mathrm{FReD})$ of Ixoderin A ( $\left.\mathrm{aa}_{44-271}\right)$ is more nearly identical to that of Ficolin $1\left(\mathrm{aa}_{109-326}, 42.54 \%\right)$ than it is to that of either Ixoderin B (aa $\left.47-276,30.04 \%\right)$ or Ixoderin C $\left(\mathrm{aa}_{231}-463,31.12 \%\right)$. The FReD confers to FRePs the ability to recognize and bind to interfacial PAMPs [31]. Some invertebrate FRePs have lectin activity, others have immunoglobulinlike domains that facilitate recognition of specific proteins [31,32]. Because FRePs opsonize and agglutinate invasive microorganisms, their primary function in invertebrates appears to be defensive [33]. Twenty-four human FRePs have been identified [34], and just as do invertebrate FRePs, many/all appear to play a role in innate immunity [34-39]. Both ficolins and ixoderins are oligomeric proteins, with higher order oligomerization integral to biologic activity [40,41].

A

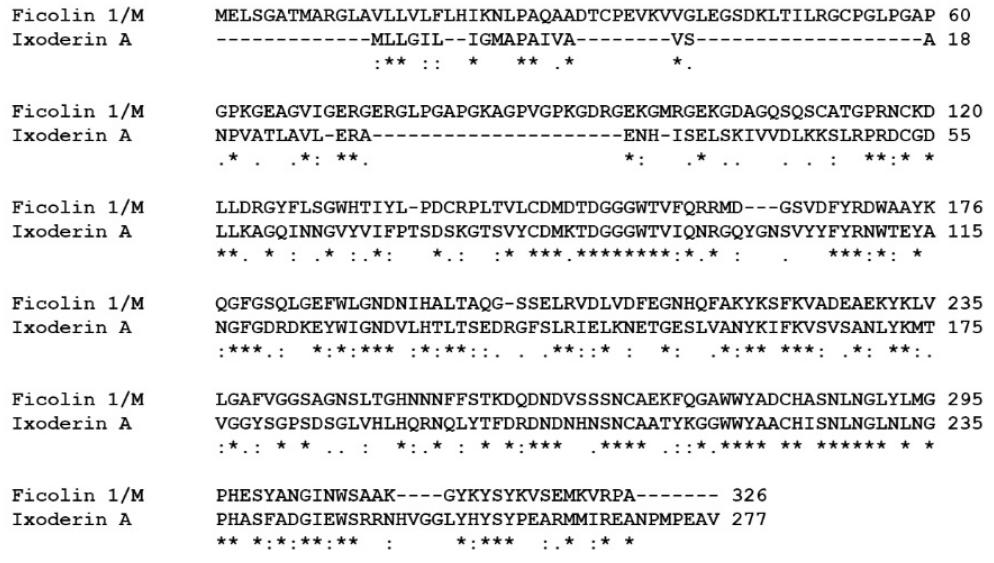

Figure 3. Cont. 


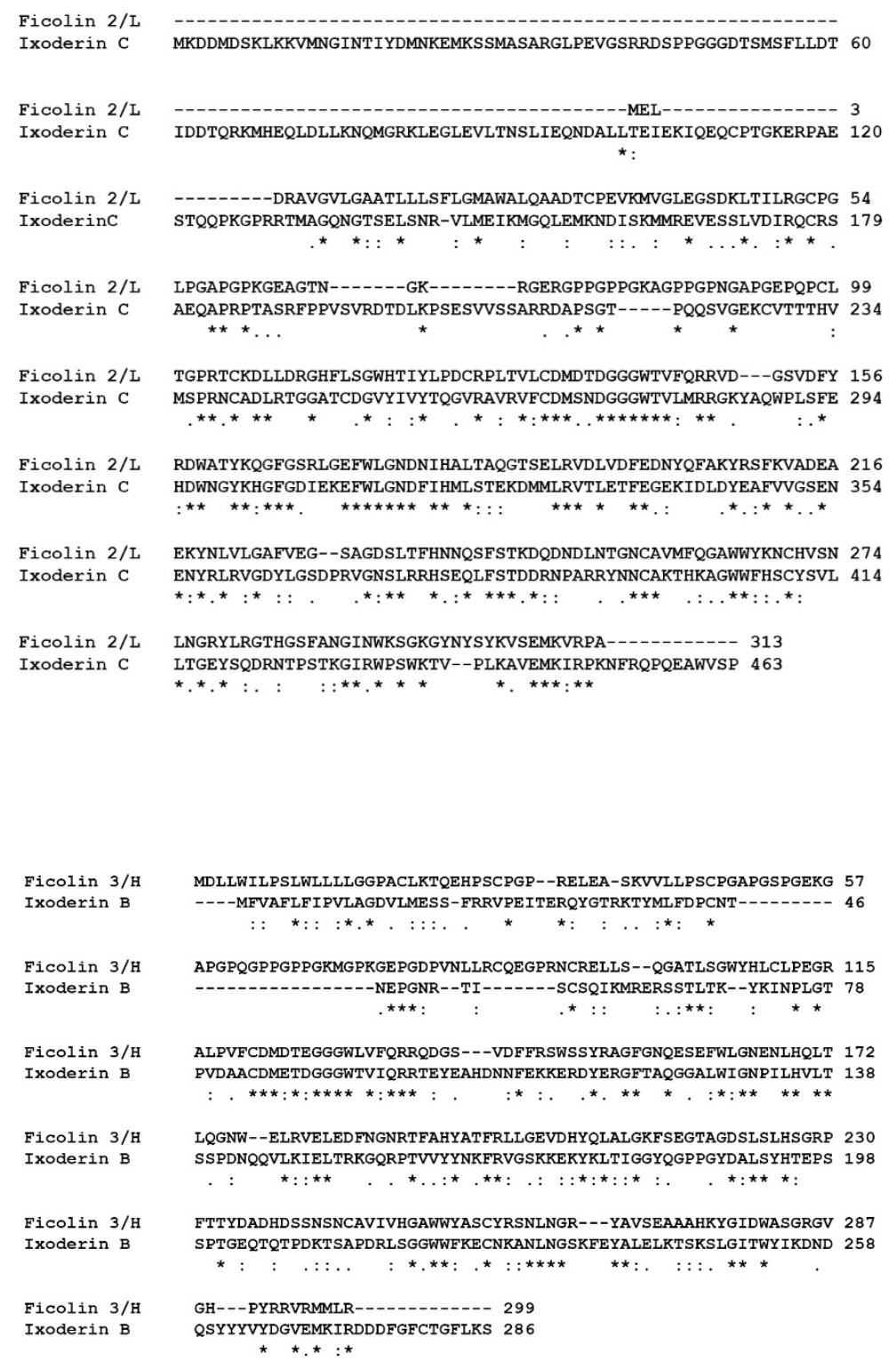

Figure 3. Sequence alignments of human ficolins and acarian ixoderins. Ficolins are paired with ixoderins with which they have greatest homology. (See Table 1). (A), Ficolin 1/M (O00602) and Ixoderin A (I6LAP5); (B), Ficolin 2/L (Q15485) and Ixoderin C (GCJO01000224); and (C), Ficolin 3/H (O75636) and Ixoderin B (Q5IUW6). An * (asterisk) indicates a position at which a single residue is fully conserved, a : (colon) indicates a position at which a substitution has strongly similar properties, and a ( period) indicates a position at which a substitution has weakly similar properties. 
Table 1. Homologies Between Ficolins of Homo sapiens and Ixoderins of Ixodes ricinus.

\begin{tabular}{|c|c|c|c|c|c|}
\hline Protein $^{1}$ & $\begin{array}{l}\text { Sequence } \\
\text { Length }^{2}\end{array}$ & $\begin{array}{l}\text { Identical } \\
\text { Positions }\end{array}$ & $\begin{array}{l}\text { Similar } \\
\text { Positions }\end{array}$ & $\begin{array}{c}\text { Global } \\
\text { Identity, }{ }^{2} \%\end{array}$ & $\begin{array}{c}\text { Tissue } \\
\text { Expression }\end{array}$ \\
\hline $\begin{array}{l}\text { Ficolin } 1 \\
(\mathrm{O} 00602)\end{array}$ & 326 & \multirow[b]{2}{*}{110} & \multirow[b]{2}{*}{80} & \multirow[b]{2}{*}{32} & $\begin{array}{c}\text { Monocytes, } \\
\text { lungs and spleen }\end{array}$ \\
\hline $\begin{array}{l}\text { Ixoderin A } \\
\text { (I6LAP5) }\end{array}$ & 277 & & & & $\begin{array}{c}\text { Hemocytes and } \\
\text { Malpighian } \\
\text { tubule }\end{array}$ \\
\hline $\begin{array}{l}\text { Ficolin } 2 \\
(\mathrm{Q} 15485)\end{array}$ & 313 & \multirow[b]{2}{*}{100} & \multirow[b]{2}{*}{83} & \multirow[b]{2}{*}{21} & $\begin{array}{l}\text { Liver (serum } \\
\text { protein) }\end{array}$ \\
\hline $\begin{array}{c}\text { Ixoderin C } \\
(\text { GCJO01000224) }\end{array}$ & 463 & & & & $\begin{array}{l}\text { Ubiquitous } \\
\text { expression in all } \\
\text { tissues; highest } \\
\text { in gut and } \\
\text { trachea }\end{array}$ \\
\hline $\begin{array}{l}\text { Ficolin } 3 \\
(\mathrm{O} 75636)\end{array}$ & 299 & \multirow{2}{*}{71} & \multirow{2}{*}{89} & \multirow{2}{*}{21} & $\begin{array}{l}\text { Gallbladder and } \\
\text { lungs }\end{array}$ \\
\hline $\begin{array}{l}\text { Ixoderin B } \\
\text { (Q5IUW6) }\end{array}$ & 286 & & & & Salivary glands \\
\hline
\end{tabular}

1 Uniprot primary accession number or European Molecular Biology Laboratory accession number. 2 Including signal peptide.

As one might expect, ficolins and ixoderins are similar functionally in that they both bind to, and facilitate the phagocytosis of, shared pathogens [24,39]. By virtue of their affinity for carbohydrates, both are categorized as lectins $[24,35,38,39]$. Their mirrored functionality is further supported by similarity of tissue expression [24,39], as seen in Table 1. Per the model espoused herein, oligomerization and lectin activity have special relevance: oligomerization, because it facilitates complexation of multiple molecular species, and lectin activity, because it confers specificity to that complexation. It comes as no surprise that antigen glycosylation influences allergenicity [42-47].

\section{Discussion}

Given the striking similarities of acarian and mammalian immune effectors, it is reasonable to propose the human immune system recognizes acarian PRRs, using them to direct responses against both the acarian, as vector, and its pathogenic payload. In fact, interspecies immune signaling applicable to humans and acarians has already been demonstrated. The well-described PRR and allergen Der $\mathrm{p} 2$ from the common dust mite, Dermatophagoides pteronyssinus, shares structural and functional homology with human MD2 [48]. In humans, MD-2 complexes with lipopolysaccharide (LPS) and LPS-binding protein (LPBP) to activate Toll-like receptor 4 (TLR4)/CD-14 expressed on leukocytes [49,50]. Der p 2 can substitute for MD-2, facilitating the binding of TLR4 to LPS [48]. Analogous interoperabilities likely exist for other structurally- and functionallyrelated molecules, e.g., human ficolin and acarian ixoderin, of phyletically distant species.

The presence of an acarian PRR on a pathogen surface conveys at least two meaningful bits of information to the mammalian system. Firstly, it signifies the underlying surface is foreign. Secondly, it informs that the source of the foreign surface is an acarian vector. This latter, in turn, enables an adaptive anti-vector response directed against the acarian and/or any vector-associated material perceived by the system to be acarian. According to this scheme, potential allergens will be ones that participated - either as intended or otherwisein pathogen complexation. In fact, this has been shown for some acarian proteins. Der p 2 and Der $\mathrm{p} 7$ are analogs of MD-2 and LPBP, respectively [48,51]. Inasmuch as MD-2 and LPBP bind LPS, Der $\mathrm{p} 2$ and Der $\mathrm{p} 7$ are likely bound to gram-negative bacteria in tick saliva and stool. The implication is that mammals with an IgE-mediated response against 
Der $\mathrm{p} 2$ or Der $\mathrm{p} 7$ had previously been exposed to gram-negative bacteria transmitted in the saliva or stool of D. pteronyssinus.

\section{Closing}

The Acari hypothesis derived from a sense that both the scale and the localization of IgE-mediated reflexes is most applicable to gross targeting of acarians, i.e., mites and ticks [18]. Given their polyphagous nature, acarians are positioned to incorporate a very significant number of dietary proteins into allergenic complexes. That said, humans are parasitized by many phyletically-distant ectoparasites, some of which are vectors. Accordingly, any ectoparasite with PRRs similar to those of man might influence human immunity by the mechanism proposed here. Review of phylogenic emergence estimates of human ectoparasites [52-58] and of IgE [59], however, indicates most ectoparasites could not have supplied the evolutionary pressure leading to the formation of IgE, Figure 4 . The Acari, on the other hand, predate emergence of IgE [58]. The only other ectoparasites predating IgE are helminths [52]. Interestingly, persons living in coastal communities where undercooked fish are consumed often have allergic responses against both fish and the piscine helminth, Anisakis simplex $[60,61]$.

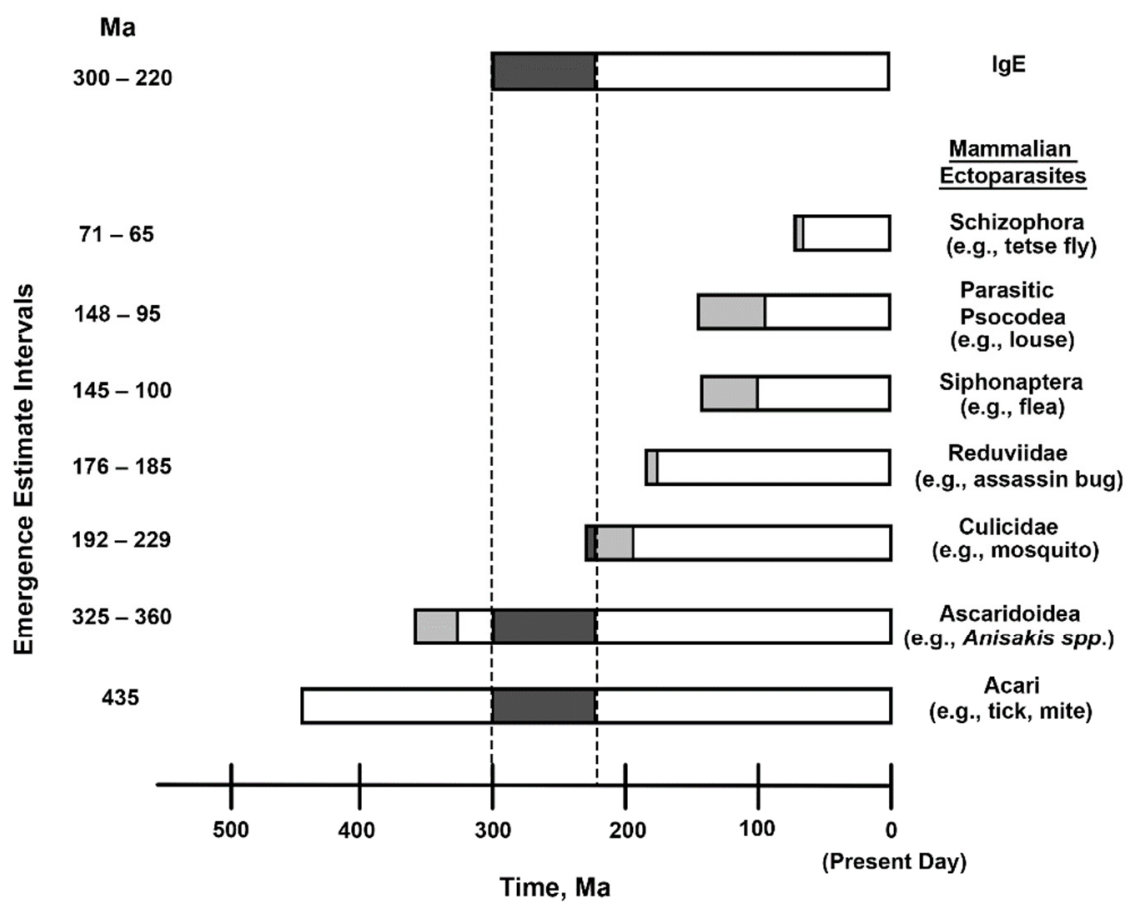

Figure 4. Relative emergences of IgE and ectoparasites of mammals. Intervals of estimated emergences are given both in the left-hand column and in the light gray shaded areas of the horizontal bars. Dashed lines and dark gray shading indicate temporal overlaps of the emergence estimates. Representative ectoparasites are given in the right-hand column.

Increasingly, research is linking IgE-mediated allergy to defense against venoms [62,63]. Because some venoms are dietary foodstuffs of acarians [64], e.g., Varroa destructor and Apis mellifera, their inclusion in allergenic complexes of the sort proposed here is not unexpected. Furthermore, many acarians produce venoms [65,66], the paralytic activity of which directly opposes mammalian IgE-mediated mechanical reflexes. Because IgE-mediated reflexes exist to defend against acarian ectoparasitism, evolution of such venoms by acarians seems a natural evolutionary response. That the anti-acarian response evolved means of managing these venoms is fitting. Finally, because acarians are close relatives of other venomous creatures, e.g., scorpions and spiders, it is conceivable that defenses against acarian venoms protects against those of closely-related species. 
One means by which to test the validity of the Acari hypothesis might be retrospective epidemiological studies targeting formula-consuming pediatric patients newly diagnosed with a milk allergy. The benefits of this particular patient population are a restricted diet and a largely supervised and controlled environment. Careful analysis of both formula stores and storage sites might yield culpable acarians, effectively relating acarian exposure to allergy. Subsequent testing and confirmation of IgE-mediated immunity to elements of the identified acarian would then imply causality.

As another means by which to test the Acari hypothesis, one could useIgE knockout rats and the tropical rat mite, Ornithonyssus bacoti, a well-described vector of several rat pathogens. Studies comparing acarian-borne pathogen transmission rates between wild-type rats and IgE knock-outs would likely be very informative.

The model described herein provides rationale relevant to the nature of allergic inflammation. If, as proposed, the binding of a foreign FReP, e.g., an ixoderin, to a molecular species directs the generation of an IgE class antibody, then it is tempting to speculate that the binding of a native FReP, e.g., a ficolin or even fibrinogen, to a molecular species might direct the generation of a different class of antibody, the theoretical and practical implications of which would be significant.

Author Contributions: Conceptualization, A.C.R.; Formal analysis, A.C.R. and G.S.R.; Visualization, A.C.R.; Writing—original draft, A.C.R.; Writing—review \& editing, G.S.R. All authors have read and agreed to the published version of the manuscript.

Funding: This research was supported in part by funding to GSR from the Department of Pathology, Feinberg School of Medicine, Northwestern University.

Institutional Review Board Statement: Not applicable.

Informed Consent Statement: Not applicable.

Data Availability Statement: Not applicable.

Conflicts of Interest: The authors declare no conflict of interest.

\section{References}

1. Commins, S.P.; Jerath, M.R.; Cox, K.; Erickson, L.D.; Platts-Mills, T. Delayed anaphylaxis to alpha-gal, an oligosaccharide in mammalian meat. Allergol. Int. 2015, 65, 16-20. [CrossRef]

2. Batard, T.; Baron-Bodo, V.; Martelet, A.; Le Mignon, M.; Lemoine, P.; Jain, K.; Mariano, S.; Horiot, S.; Chabre, H.; Harwanegg, C.; et al. Patterns of IgE sensitization in house dust mite-allergic patients: Implications for allergen immunotherapy. Allergy 2015, 71, 220-229. [CrossRef]

3. Calderón, M.A.; Linneberg, A.; Kleine-Tebbe, J.; De Blay, F.; de Rojas, D.H.F.; Virchow, J.C.; Demoly, P. Respiratory allergy caused by house dust mites: What do we really know? J. Allergy Clin. Immunol. 2014, 136, 38-48. [CrossRef]

4. Kim, C.-R.; Jeong, K.Y.; Yi, M.-H.; Kim, H.-P.; Shin, H.-J.; Yong, T.-S. Cross-reactivity between group-5 and -21 mite allergens from Dermatophagoides farinae, Tyrophagus putrescentiae and Blomia tropicalis. Mol. Med. Rep. 2015, 12, 5467-5474. [CrossRef] [PubMed]

5. Hubert, J.; Nesvorna, M.; Klimov, P.; Dowd, S.E.; Sopko, B.; Erban, T. Differential allergen expression in three Tyrophagus putrescentiae strains inhabited by distinct microbiome. Allergy 2019, 74, 2502-2507. [CrossRef] [PubMed]

6. Jakubas-Zawalska, J.; Asman, M.; Solarz, K. Sensitization to the storage mites Lepidoglyphus destructor and Tyrophagus pu-trescentiae (Acari, Sarcoptiformes, Astigmatina) in a suburban population in Southern Poland. Ann. Parasitol. 2017, 63, 183-188. [CrossRef]

7. Matsumoto, T.; Hisano, T.; Hamaguchi, M.; Miike, T. Systemic Anaphylaxis after Eating Storage-Mite-Contaminated Food. Int. Arch. Allergy Immunol. 1996, 109, 197-200. [CrossRef] [PubMed]

8. Sanchez-Borges, M.; Capriles-Hulett, A.; Fernandez-Caldas, E.; Suarez-Chacon, R.; Caballero, F.; Castillo, S.; Sotillo, E. Mitecontaminated foods as a cause of anaphylaxis1. J. Allergy Clin. Immunol. 1997, 99, 738-743. [CrossRef]

9. Johansson, E.; Kolmodin-Hedman, B.; Kallstrom, E.; Kaiser, L.; van Hage-Hamsten, M. IgE-mediated sensitization to predatory mites in Swedish greenhouse workers. Allergy 2003, 58, 337-341. [CrossRef]

10. Spieksma, F.T.M. Domestic mites from an acarologic perspective. Allergy 1997, 52, 360-368. [CrossRef]

11. Li, C.; Zhan, X.; Sun, E.; Zhao, J.; Wang, H.; He, J.; Wang, J. The density and species of mite breeding in stored products in China. Nutr. Hosp. 2014, 31, 798-807. [CrossRef] [PubMed]

12. Hubert, J.; Stejskal, V.; Munzbergová, Z.; Kubátová, A.; Váňová, M.; Žd'Árková, E. Mites and Fungi in Heavily Infested Stores in the Czech Republic. J. Econ. Ėntomol. 2004, 97, 2144-2153. [CrossRef] [PubMed] 
13. Olsen, A.R. Mites and Other Filth in Dried Shrimp Imported into the United States From the Orient. J. Food Prot. 1982, 45, 1204-1207. [CrossRef]

14. Somerfield, K.G.; Manson, D.C.M.; Dale, P.S. Insects and mites associated with dried milk product storage areas in New Zealand. N. Z. J. Exp. Agric. 1980, 8, 83-85. [CrossRef]

15. Karagoz, E.U.; Akdemir, C.; Direkel, S.; Guler, N.C. The Investigation of the Presence of Mites in Some Served Dry Foodstuffs. Turk. Parazitol. Derg. 2017, 41, 92-95. [CrossRef] [PubMed]

16. Vijayambika, V.; John, P.A. Internal morphology of the hypopus of Lardoglyphus konoi, a tyroglyphid pest on dried stored fish. Acarologia 1973, 15, 342-348.

17. Gupta, A.; Sharma, Y.K. Human demodex mite: The versatile mite of dermatological importance. Indian J. Dermatol. 2014, 59, 302. [CrossRef]

18. Retzinger, A.C.; Retzinger, G.S. Mites, ticks, anaphylaxis and allergy: The Acari hypothesis. Med. Hypotheses 2020, $144,110257$. [CrossRef] [PubMed]

19. Ren, Y.; Ding, Q.; Zhang, X. Ficolins and infectious diseases. Virol. Sin. 2014, 29, 25-32. [CrossRef]

20. Sorrell, T.C.; Chen, S.C.A. Fungal-Derived Immune Modulating Molecules. Adv. Exp. Med. Biol. 2009, 666, 108-120. [CrossRef]

21. Jun, J.-I.; Lau, L.F. CCN1 is an opsonin for bacterial clearance and a direct activator of Toll-like receptor signaling. Nat. Commun. 2020, 11, 1242. [CrossRef]

22. Hajdušek, O.; Šíma, R.; Ayllón, N.; Jalovecká, M.; Perner, J.; De La Fuente, J.; Kopáček, P. Interaction of the tick immune system with transmitted pathogens. Front. Cell. Infect. Microbiol. 2013, 3, 26. [CrossRef] [PubMed]

23. Inoue, N.; Hanada, K.; Tsuji, N.; Igarashi, I.; Nagasawa, H.; Mikami, T.; Fujisaki, K. Characterization of Phagocytic Hemocytes in Ornithodoros moubata (Acari: Ixodidae). J. Med. Ėntomol. 2001, 38, 514-519. [CrossRef] [PubMed]

24. Mondeková, H.H.; Sima, R.; Urbanová, V.; Kovar, V.; Rego, R.; Grubhoffer, L.; Kopacek, P.; Hajdusek, O. Characterization of Ixodes ricinus Fibrinogen-Related Proteins (Ixoderins) Discloses Their Function in the Tick Innate Immunity. Front. Cell. Infect. Microbiol. 2017, 7, 509. [CrossRef]

25. Šimo, L.; Kazimirova, M.; Richardson, J.; Bonnet, S.I. The Essential Role of Tick Salivary Glands and Saliva in Tick Feeding and Pathogen Transmission. Front. Cell. Infect. Microbiol. 2017, 7, 281, Published 2017 Jun 22. [CrossRef]

26. Tjernberg, I.; Hamsten, C.; Apostolovic, D.; Van Hage, M. IgE reactivity to $\alpha$-Gal in relation to Lyme borreliosis. PLoS ONE 2017, 12, e0185723. [CrossRef]

27. Rego, R.O.; Hajdusek, O.; Kovář, V.; Kopáček, P.; Grubhoffer, L.; Hypša, V. Molecular cloning and comparative analysis of fibrinogen-related proteins from the soft tick Ornithodoros moubata and the hard tick Ixodes ricinus. Insect Biochem. Mol. Biol. 2005, 35, 991-1004. [CrossRef] [PubMed]

28. Martins, L.A.; Galletti, M.F.B.D.M.; Ribeiro, J.M.; Fujita, A.; Costa, F.B.; Labruna, M.B.; Daffre, S.; Fogaça, A.C. The Distinct Transcriptional Response of the Midgut of Amblyomma sculptum and Amblyomma aureolatum Ticks to Rickettsia rickettsii Correlates to Their Differences in Susceptibility to Infection. Front. Cell. Infect. Microbiol. 2017, 7, 129. [CrossRef]

29. Kovář, V.; Kopáček, P.; Grubhoffer, L. Isolation and characterization of Dorin M, a lectin from plasma of the soft tick Ornithodoros moubata. Insect Biochem. Mol. Biol. 2000, 30, 195-205. [CrossRef]

30. Rego, R.; Kovar, V.; Kopacek, P.; Weise, C.; Man, P.; Sauman, I.; Grubhoffer, L. The tick plasma lectin, Dorin M, is a fibrinogenrelated molecule. Insect Biochem. Mol. Biol. 2006, 36, 291-299. [CrossRef]

31. Doolittle, R.F.; McNamara, K.; Lin, K. Correlating structure and function during the evolution of fibrinogen-related domains. Protein Sci. 2012, 21, 1808-1823. [CrossRef]

32. Cerenius, L.; Söderhäll, K. Variable immune molecules in invertebrates. J. Exp. Biol. 2013, 216, 4313-4319. [CrossRef]

33. Hanington, P.C.; Zhang, S.-M. The Primary Role of Fibrinogen-Related Proteins in Invertebrates Is Defense, Not Coagulation. J. Innate Immun. 2011, 3, 17-27. [CrossRef] [PubMed]

34. Zuliani-Alvarez, L.; Marzeda, A.; Deligne, C.; Schwenzer, A.; McCann, F.E.; Marsden, B.D.; Piccinini, A.M.; Midwood, K.S. Mapping tenascin-C interaction with toll-like receptor 4 reveals a new subset of endogenous inflammatory triggers. Nat. Commun. 2017, 8, 1595. [CrossRef]

35. Endo, Y.; Matsushita, M.; Fujita, T. New Insights into the Role of Ficolins in the Lectin Pathway of Innate Immunity. Int. Rev. Cell Mol. Biol. 2015, 316, 49-110. [CrossRef]

36. Mörgelin, M.; Kasetty, G.; Olin, A.I.; Schmidtchen, A.; Herwald, H.; Påhlman, L.I. Antimicrobial activity of fibrinogen and fibrinogen-derived peptides-A novel link between coagulation and innate immunity. Thromb. Haemost. 2013, 109, 930-939. [CrossRef]

37. Smiley, S.T.; King, J.A.; Hancock, W.W. Fibrinogen Stimulates Macrophage Chemokine Secretion Through Toll-Like Receptor 4. J. Immunol. 2001, 167, 2887-2894. [CrossRef] [PubMed]

38. Endo, Y.; Matsushita, M.; Fujita, T. The role of ficolins in the lectin pathway of innate immunity. Int. J. Biochem. Cell Biol. 2011, 43, 705-712. [CrossRef] [PubMed]

39. Bidula, S.; Sexton, D.W.; Schelenz, S. Ficolins and the Recognition of Pathogenic Microorganisms: An Overview of the Innate Immune Response and Contribution of Single Nucleotide Polymorphisms. J. Immunol. Res. 2019, 2019, 1-13. [CrossRef] [PubMed]

40. Casals, C.; García-Fojeda, B.; Minutti, C.M. Soluble defense collagens: Sweeping up immune threats. Mol. Immunol. 2019, 112, 291-304. [CrossRef] 
41. Grubhoffer, L.; Kovář, V.; Rudenko, N. Tick lectins: Structural and functional properties. Parasitology 2004, 129, S113-S125. [CrossRef] [PubMed]

42. Md, A.; Maeda, M.; Matsui, T.; Takasato, Y.; Ito, K.; Kimura, Y. Purification and molecular characterization of a truncated-type Ara h 1, a major peanut allergen: Oligomer structure, antigenicity, and glycoform. Glycoconj. J. 2021, 38, 67-76. [CrossRef] [PubMed]

43. Zhang, Z.; Xiao, H.; Zhou, P. Glycation by saccharides of different molecular sizes affected the allergenicity of shrimp tropomyosin via epitope loss and the generation of advanced glycation end products. Food Funct. 2019, 10, 7042-7051. [CrossRef] [PubMed]

44. Altmann, F. The Role of Protein Glycosylation in Allergy. Int. Arch. Allergy Immunol. 2006, 142, 99-115. [CrossRef] [PubMed]

45. Al-Ghouleh, A.; Johal, R.; Sharquie, I.K.; Emara, M.; Harrington, H.; Shakib, F.; Ghaemmaghami, A.M. The Glycosylation Pattern of Common Allergens: The Recognition and Uptake of Der $\mathrm{p} 1$ by Epithelial and Dendritic Cells Is Carbohydrate Dependent. PLoS ONE 2012, 7, e33929. [CrossRef]

46. Halim, A.; Carlsson, M.C.; Madsen, C.B.; Brand, S.; Möller, S.R.; Olsen, C.E.; Vakhrushev, S.; Brimnes, J.; Wurtzen, P.A.; Ipsen, H.; et al. Glycoproteomic Analysis of Seven Major Allergenic Proteins Reveals Novel Post-translational Modifications. Mol. Cell. Proteom. 2015, 14, 191-204. [CrossRef] [PubMed]

47. Batanero, E.; Villalba, M.; Rodríouez, R. Glycosylation site of the major allergen from olive tree pollen. Allergenic implications of the carbohydrate moiety. Mol. Immunol. 1994, 31, 31-37. [CrossRef]

48. Trompette, A.; Divanovic, S.; Visintin, A.; Blanchard, C.; Hegde, R.S.; Madan, R.; Thorne, P.; Wills-Karp, M.; Gioannini, T.L.; Weiss, J.P.; et al. Allergenicity resulting from functional mimicry of a Toll-like receptor complex protein. Nature 2008, 457, 585-588. [CrossRef] [PubMed]

49. Shimazu, R.; Akashi, S.; Ogata, H.; Nagai, Y.; Fukudome, K.; Miyake, K.; Kimoto, M. MD-2, a Molecule that Confers Lipopolysaccharide Responsiveness on Toll-like Receptor 4. J. Exp. Med. 1999, 189, 1777-1782. [CrossRef]

50. Jerala, R. Structural biology of the LPS recognition. Int. J. Med. Microbiol. 2007, 297, 353-363. [CrossRef]

51. Mueller, G.A.; Edwards, L.L.; Aloor, J.J.; Fessler, M.; Glesner, J.; Pomés, A.; Chapman, M.; London, R.E.; Pedersen, L. The structure of the dust mite allergen Der p 7 reveals similarities to innate immune proteins. J. Allergy Clin. Immunol. 2010, 125, 909-917.e4. [CrossRef] [PubMed]

52. Li, L.; Lü, L.; Nadler, S.A.; Gibson, D.I.; Zhang, L.-P.; Chen, H.-X.; Zhao, W.-T.; Guo, Y.-N. Molecular Phylogeny and Dating Reveal a Terrestrial Origin in the Early Carboniferous for Ascaridoid Nematodes. Syst. Biol. 2018, 67, 888-900. [CrossRef] [PubMed]

53. Junqueira, A.C.M.; Azeredo-Espin, A.M.L.; Paulo, D.; Marinho, M.A.T.; Tomsho, L.P.; Drautz-Moses, D.I.; Purbojati, R.W.; Ratan, A.; Schuster, S.C. Large-scale mitogenomics enables insights into Schizophora (Diptera) radiation and population diversity. Sci. Rep. 2016, 6, 21762. [CrossRef] [PubMed]

54. Zhu, Q.; Hastriter, M.W.; Whiting, M.F.; Dittmar, K. Fleas (Siphonaptera) are Cretaceous, and evolved with Theria. Mol. Phylogenet. Evol. 2015, 90, 129-139. [CrossRef] [PubMed]

55. de Moya, R.S.; Yoshizawa, K.; Walden, K.K.O.; Sweet, A.D.; Dietrich, C.H.; Johnson, K.P. Phylogenomics of Parasitic and Nonparasitic Lice (Insecta: Psocodea): Combining Sequence Data and Exploring Compositional Bias Solutions in Next Generation Data Sets. Syst. Biol. 2020, 70, 719-738. [CrossRef]

56. Hwang, W.S.; Weirauch, C. Evolutionary History of Assassin Bugs (Insecta: Hemiptera: Reduviidae): Insights from Divergence Dating and Ancestral State Reconstruction. PLoS ONE 2012, 7, e45523. [CrossRef] [PubMed]

57. Reidenbach, K.R.; Cook, S.; Bertone, M.A.; Harbach, R.E.; Wiegmann, B.M.; Besansky, N.J. Phylogenetic analysis and temporal diversification of mosquitoes (Diptera: Culicidae) based on nuclear genes and morphology. BMC Evol. Biol. 2009, 9, 298. [CrossRef] [PubMed]

58. Dabert, M.; Witalinski, W.; Kaźmierski, A.; Olszanowski, Z.; Dabert, J. Molecular phylogeny of acariform mites (Acari, Arachnida): Strong conflict between phylogenetic signal and long-branch attraction artifacts. Mol. Phylogenet. Evol. 2010, 56, $222-241$. [CrossRef] [PubMed]

59. Hellman, L.T.; Akula, S.; Thorpe, M.; Fu, Z. Tracing the Origins of IgE, Mast Cells, and Allergies by Studies of Wild Animals. Front. Immunol. 2017, 8, 1749. [CrossRef]

60. Morishima, R.; Motojima, S.; Tsuneishi, D.; Kimura, T.; Nakashita, T.; Fudouji, J.; Ichikawa, S.; Ito, H.; Nishino, H. Anisakis is a major cause of anaphylaxis in seaside areas: An epidemiological study in Japan. Allergy 2019, 75, 441-444. [CrossRef]

61. Aibinu, I.; Smooker, P.; Lopata, A.L. Anisakis Nematodes in Fish and Shellfish- from infection to allergies. Int. J. Parasitol. Parasites Wildl. 2019, 9, 384-393. [CrossRef]

62. Galli, S.J.; Metz, M.; Starkl, P.; Marichal, T.; Tsai, M. Mast cells and IgE in defense against lethality of venoms: Possible "benefit" of allergy. Allergo J. Int. 2020, 29, 46-62. [CrossRef] [PubMed]

63. Starkl, P.; Gaudenzio, N.; Marichal, T.; Reber, L.L.; Sibilano, R.; Watzenboeck, M.L.; Fontaine, F.; Mueller, A.C.; Tsai, M.; Knapp, S.; et al. IgE antibodies increase honeybee venom responsiveness and detoxification efficiency of mast cells. Allergy 2021. [CrossRef] [PubMed]

64. Erban, T.; Harant, K.; Hubalek, M.; Vitamvas, P.; Kamler, M.; Poltronieri, P.; Tyl, J.; Markovic, M.; Titera, D. In-depth proteomic analysis of Varroa destructor: Detection of DWV-complex, ABPV, VdMLV and honeybee proteins in the mite. Sci. Rep. 2015, 5, srep13907. [CrossRef]

65. Cabezas-Cruz, A.; Valdés, J.J. Are ticks venomous animals? Front. Zool. 2014, 11, 47. [CrossRef] [PubMed]

66. Pienaar, R.; Neitz, A.W.H.; Mans, B.J. Tick Paralysis: Solving an Enigma. Vet. Sci. 2018, 5, 53. [CrossRef] [PubMed] 